\title{
International Staging System for Myeloma
}

National Cancer Institute

\section{Source}

National Cancer Institute. International Staging System for Myeloma. NCI Thesaurus.

Code C70657.

A method of staging myeloma published by the International Myeloma Working Group in 2003. 